\title{
Improvement of Strength and Radiation Protection Properties of Biodegradable Jute Fiber Reinforced Material
}

\author{
S. Verma, ${ }^{1}$ S. S. Amritphale, and S. Das \\ Council of Scientific and Industrial Research - Advanced Materials and Processes Research Institute, \\ Bhopal, India \\ ${ }^{1}$ drsarikaverma@hotmail.com
}

УДК 539.4

\section{Разработка биодеградируемого джутоволоконного материала с высокими прочностными и радиационно-защитными свойствами}

\author{
С. Верма, С. С. Амритфал, С. Дас
}

Научно-исследовательский институт высокотехнологичных материалов и процессов, Бхопал, Индия

В настоящее время широкое применение получили композиты, армированные натуральными волокнами (экокомпозиты). В отличие от стеклопластиков, они подвержены биодеградации и безвредны для окружающей среды, имеют низкую стоимость и плотность, не выделяют вредных веществ при горении и расщепляются микроорганизмами. Предложена новая технология производства из краснозема биодеградируемого джутоволоконного материала с высокими прочностными и радиационно-защитными свойствами. Оценень проницаемость его рентгеновскими лучами, статическая прочность при разрыве и изгибе, а также ударная прочность. Проведены микроструктурные исследования. Полученные результать подтверждают перспективность предложенной технологии производства из данного материала защитных панелей для рентгеновских кабинетов и другого оборудования радиащионной защить.

Ключевые слова: красный шлам, рентгеновское излучение, нетоксичность, затухание, джутовое волокно, армирование, биодеградация.

Introduction. The importance of all the types of radiations in living beings' life is well known. For example, work without using X-rays radiation in diagnostics X-rays and in $\mathrm{CT}$ scanner room is beyond imagination. But along with their usefulness, they have severe harmful effects, if not taken care and for the same one should use radiation protection materials. Although researchers have developed various traditional materials using compounds of lead, tungsten, barium, rare earth in the matrix of concrete and polymers for radiation protection material $[1,2]$, but due to their certain drawbacks like toxicity, heavy cost etc. there is an urgent need to develop an alternative methodology for developing non-toxic and economical radiation protection material.

Further, from the environmental stringent rules and regulations, increased environmental awareness and societal needs, excessive use of petroleum resources, have also attracted the material scientist and researchers towards eco-friendly, biodegradable, green materials and have encouraged them for developing advanced eco-friendly composite materials which are compatible with the environment. Further, the natural fiber reinforced biodegradable composite material gives better properties over other traditional composites, which uses conventional reinforcing fibers like Kevlar, glass, carbon. In recent years the 
use of natural fibers (NF) as reinforcement in composites had increased as these natural fibers reinforced composites have potential to save the environment from pollution due to their ultimate disposability property and are also titled as eco-composites. NF are low cost, low density, high toughness, biodegradability, renewability, reduced tool wear (nonabrasive to processing equipment), more energy recovery, carbon dioxide neutral when burned and are present abundantly in nature [3].

Broadly the NFs are classified as leaf, bast, seed, and fruit depending on the origin. Among this bast and leaf (hard fiber) types of fiber are commonly used in composite application [4, 5]. Examples of bast fibers include hemp, jute, flax, ramie and kenaf. Mohanty et al. [6] have reported that the NF reinforced composites have potential to replace glass fiber reinforced composites. NEC Corp. (Tokyo, Japan) and UNITIKA (Tokyo, Japan) has announced the joint development of kenaf fiber-reinforced PLA [7]. Further, it is well-known fact that the major constituents of the natural fibers are cellulose, hemicellulose and lignin and the Mechanical properties of the NF are determined mainly by the cellulose content and microfibrillar angle. A high cellulose content and low microfibril angle are desirable properties of a fiber to be used as reinforcement in polymer composites. Among all natural fibers, jute is the most inexpensive, useful and commercially available fibers. Jute fiber consists of about $65-70 \%$ cellulose, $13.6-20.4 \%$ hemicellulose, and $8 \%$ microfibril [8]. The constituents of jute fiber reveal that it can be a potential candidate for reinforcement in bio-composites. Further, as the jute fiber has good biocompatibility with varying polymers including thermoplastics, e.g., polyethylene, polyvinyl chloride, and polypropylene as well as thermosets like unsaturated polyester and epoxy resin, they can be successfully used as reinforcement in developing advanced, non-toxic, biodegradable material. Enormous work has been reported related to the development of polyester composites, in a varying matrix using jute fiber reinforcement.

Further, among various industrial waste, red mud is an aluminum industry waste and approximately two tones of red mud are generated for every tone of aluminum production from about 85 alumina plants all over the world and thus leading to the generation of about 77 million tons waste is generation [9, 10]. Red mud waste is a best suitable and appropriate multi-component resource material for developing multi-phases containing shielding material as it inherently contains varieties of elements, namely iron, titanium, aluminum, silicon, calcium, magnesium, and sodium etc. Researchers have reported the use of red mud-based polyester composites. For example, Verma et al. [11] has reported the development of advanced, X-ray radiation shielding panels by utilizing red mud-based polymeric organic shielding gel type material. Akinci et al. [12] have shown the use of red mud with polyester resin. Bindal et al. [13] have reported the development of glass/jute fibers reinforced polyester composite. Considerable research work has been carried out on the development of radiation shielding material utilizing industrial waste, but to the best of our knowledge, no work has been reported regarding the development of advanced, non-toxic, biodegradable, jute fiber reinforced, X-ray radiation protection materials by utilizing red mud-based gel.

Taking into account all the above-mentioned factors, the objective of the current study is the Improvement of strength and radiation protection properties of biodegradable jute fiber reinforced material by utilizing red mud-based gel. The process involves the use of multi-elemental; multicomponent processed red mud-based gel. Furthermore, for the fabrication of advanced X-ray shielding composite panels, the closed molding system has been applied using hand lay-up manual technique using jute fiber reinforcement. The developed polymeric organic gel can easily be used and molded in desired shapes and dimensions for its wide application spectrum. Compression molding, pultruding and resin transfer molding, vacuum molding etc. are among the list of many techniques which are available in the market for the manufacturing of composites, but the hand lay-up manual 
technique is one of the cheapest, easiest and simplest ways of fabricating the composites. By this technique, one can fabricate very large, complex parts with reduced manufacturing times and can get the sample of desired dimensions [14].

Thus, the present study deals with the improvement of strength and radiation protection properties of biodegradable jute fiber reinforced material in the form of panels, by utilizing red mud-based gel and their morphological characterization along with radiation protection and mechanical properties.

\section{Experimental.}

\subsection{Materials and Methods.}

1.1.1. Chemicals. Red mud was obtained from Hindustan Aluminum Company (HINDALCO) Renukoot, India and was used unaltered. The chemical composition of red mud was determined by using conventional wet chemical analysis method [15] and the result shows the presence of $\mathrm{Al}_{2} \mathrm{O}_{3}, \mathrm{Fe}_{2} \mathrm{O}_{3}, \mathrm{SiO}_{2}, \mathrm{TiO}_{2}$.

Barium sulfate, carbon powder, methyl ethylketone peroxide (MEKP) and cobalt octoate were procured from Rankem. The matrix material was unsaturated polyester resin (UPR) of 205 LV codes, which is thermoplastic resin and was supplied by Satyam polymers, Gujarat, India. Jute fiber mats were obtained from local market. All the chemicals were used as such without further purification.

1.1.2. Procedure. The black colored tailored shielding precursor powder of red mud was obtained as reported earlier in our previous work [11]. Further, the developed shielding powder was thoroughly blended with unsaturated polyester resin to form a dilatant resin mixture which was further compounded with methylethyl ketone peroxide and cobalt octoate to form a thick viscous radiation shielding gel-based material. It was then placed in a closed mold fabrication system with a gel coating, using hand layup manual technique. The jute fiber layer as reinforcement was manually fitted in-between the viscous shielding gel-based material and was pressed for $4 \mathrm{~h}$ using $25 \mathrm{~kg}$ load. The samples were de-molded and result in the formation of newly advanced biodegradable radiation protection material in the form of panels. Subsequently, the samples were covered with thin plastic film and cured at $60^{\circ} \mathrm{C}$ in an oven for $24 \mathrm{~h}$. Different formulations of advanced, non-toxic, biodegradable, jute fiber reinforced, X-ray radiation protection materials in the form of panels were prepared by varying the amount of jute fiber reinforcement layer as shown in Table 1 below. The process is schematically shown in Fig. 1.

\subsection{Characterization.}

1.2.1. Scanning Electron Micrographs. The scanning electron micrographs of red mud, tailored shielding powder of red mud, Jute fiber as such and advanced, non-toxic, biodegradable, Jute fiber reinforced, X-ray radiation protection material in the form of panels were examined using a JEOL model JEM-35-CF scanning electron microscope. The samples were mounted on aluminum stubs using carbon tape and then coated with a thin layer of platinum to prevent charging before the observation.

1.2.2. X-Ray Radiation Shielding Attenuation Properties. The X-ray radiation shielding attenuation properties of advanced, non-toxic, biodegradable, jute fiber reinforced, X-ray radiation protection material in the form of panels were studied using Nomex Multimeter from PTW. The readings are taken from the range of 40 to $100 \mathrm{kVp}$. The X-ray machine used for testing is DX 525 - a $500 \mathrm{~mA}, 125 \mathrm{kVp}$ X-ray machine of Wipro GE make.

\subsection{Mechanical Properties.}

1.3.1. Flexural Strength. The standard test method, ASTM D790-17 [16], for flexural properties of developed advanced, non-toxic, biodegradable, jute fiber reinforced, X-ray radiation protection material in the form of panels have been used. The flexural strength was carried out as per the American society for testing and materials standards [16]. In this test at the middle of the sample, when a load is applied, then the sample become bends and thus breaches. 
$\mathrm{T}$ a b 1 e 1

Different Formulations and Properties of Developed Advanced, Non-Toxic, Biodegradable, Jute Fiber Reinforced, X-Ray Radiation Protection Material in the Form of Panels

\begin{tabular}{|c|c|c|c||}
\hline No. & \multicolumn{1}{|c|}{ Characteristic } & \multicolumn{2}{c|}{ Advanced material in the form of panels } \\
\hline 1 & Weight $(\mathrm{g})$ & A & B \\
\hline a & $\begin{array}{l}\text { Red mud-based black colored tailored } \\
\text { shielding precursor powder }\end{array}$ & 900 & 1600 \\
\hline b & Unsaturated polyester resin (UPR) & 500 & 855 \\
\hline c & Jute fiber reinforcement & 324 & 544 \\
\hline d & Advanced panels & 1724 & 3024 \\
\hline 2 & Dimensions $\left(\mathrm{cm}^{2}\right.$ & $30 \times 30 \times 0.5$ & $30 \times 30 \times 1$ \\
\hline 3 & Density $\left(\mathrm{g} / \mathrm{cm}^{3}\right)$ & 2.6 & 2.9 \\
\hline 4 & Colour & Black & Black \\
\hline
\end{tabular}

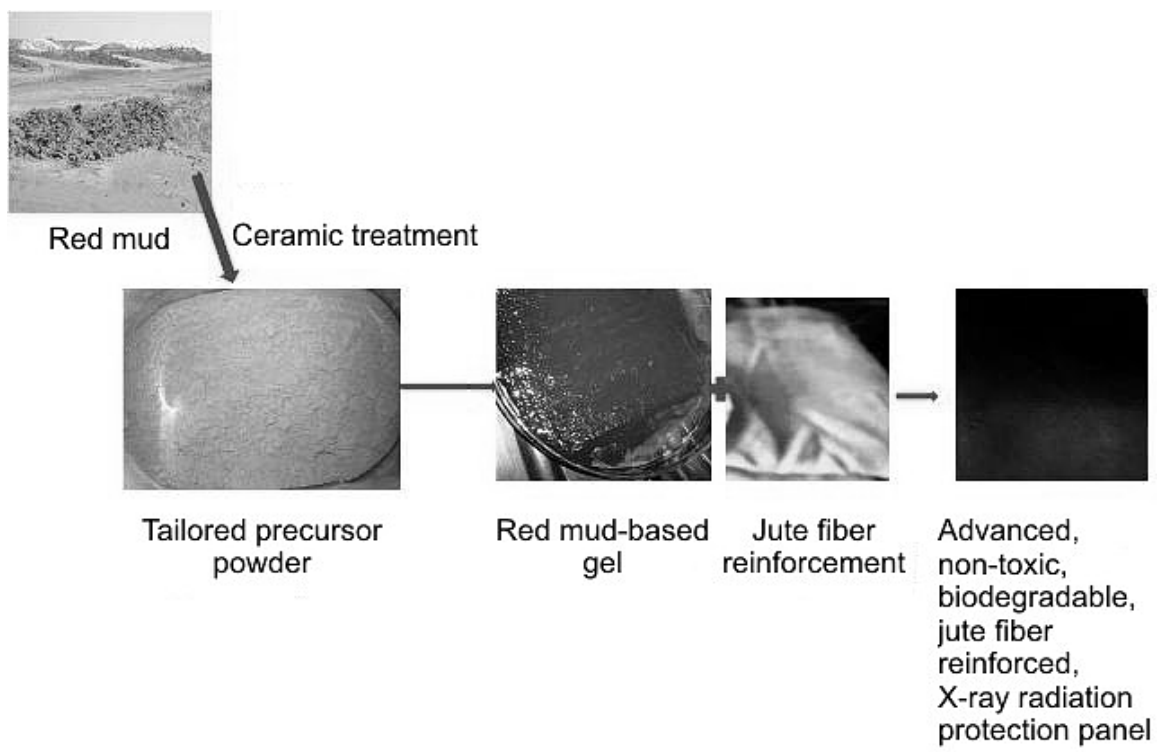

Fig. 1. Scheme of the proposed preparation process of panels.

1.3.2. Tensile Strength. The standard test method, ASTM D 638-14 [17], for tensile properties of developed advanced, non-toxic, biodegradable, jute fiber reinforced, X-ray radiation protection material in the form of panels have been used. The tensile test was carried out on tensometer, as per the American society for testing and materials standards. The test specimens are prepared as per ASTM D638-14 $(33 \times 6 \times 4 \mathrm{~mm})$ [17]. The load was applied to the sample when they were held in the grip and the corresponding deflections are noted. The load is applied until the specimen breaks and then the ultimate tensile strengths are noted.

1.3.3. Impact Strength. The standard test method, ASTM D256-10 [18], for impact strength property has been used to test the developed advanced, non-toxic, biodegradable, jute fiber reinforced, X-ray radiation protection material in the form of panels. The impact 
strength was carried out as per the American society for testing and materials standards [18]. Using this test, the energy needed to break the sample is noted, which is used to measure the toughness and the yield strength of the sample. The sample was loaded in the testing machine and the pendulum was allowed to move until it breaks.

1.3.4. Water Absorption Test. The developed advanced, non-toxic, biodegradable, jute fiber reinforced, X-ray radiation protection material in the form of panels were completely immersed into the water bath at $25^{\circ} \mathrm{C}$ to test water uptake. The weight of the samples was recorded after different contact times. Samples were wiped carefully to remove surface water before weighing. The increase in the weight of the wet sample determines the extent of water uptake. The amount of water uptake was monitored periodically up to $25 \mathrm{~min}$. Water uptake is determined using the standard equation [19].

\section{Results and Discussion.}

2.1. Advanced, Non-Toxic, Biodegradable, Jute Fiber Reinforced, X-Ray Radiation Protection Material in the Form of Panels.

2.1.1. Dimensions. The jute fiber reinforced advanced, non-toxic, biodegradable $\mathrm{X}$-ray radiation shielding material in the form of panels were cast to obtain the panel of the dimensions $30 \times 30 \times 0.5 \mathrm{~cm}$ and $30 \times 30 \times 1 \mathrm{~cm}$, respectively, as mentioned in Table 1 .

2.1.2. Density Analysis. The density of both the jute fiber reinforced advanced, non-toxic biodegradable X-ray radiation shielding material in the form of panels were calculated and is reported in Table 1.

\subsection{Morphological Studies.}

2.2.1. Scanning Electron Microphotography (SEM). The SEM exhibiting microstructure of red mud as such and tailored shielding precursor powder of red mud, jute fiber and developed panels has been studied. The microphotographs exhibiting microstructure of red mud as such confirms the presence of multi-elemental constituent present in it and tailored shielding precursor powder of red mud having multi-component, multi-phase and multi-layered structure having shielding properties as reported in our earlier work [11]. Further, the scanning electron microphotograph of jute fiber is shown in Fig. 2a which showed it to be thick and curved in nature. They have different morphological features, as compared to glass fibers.

A typical cross-sectional, fractured scanning electron microscopy images of developed non-toxic, biodegradable radiation shielding panels were examined to study the fracture surface morphology, interfacial properties along with adhesive tendency between the two As displayed in Fig. $2 b$ below the scanning electron microscopy analysis of fracture surfaces illustrates the wonderful interaction between the jute fiber reinforcement and red mud-based alkaline matrix.

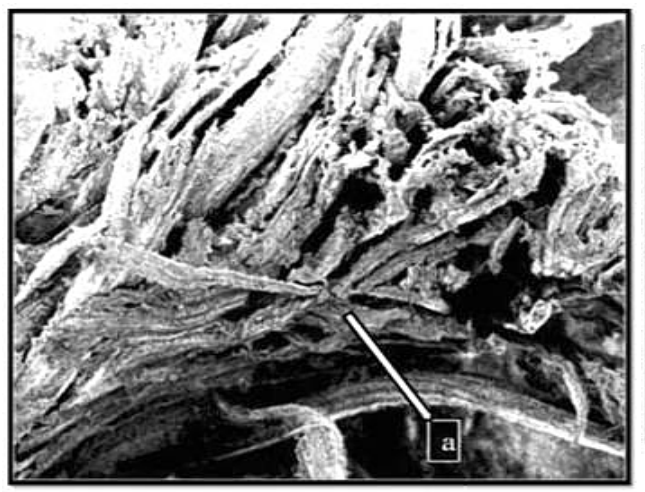

a

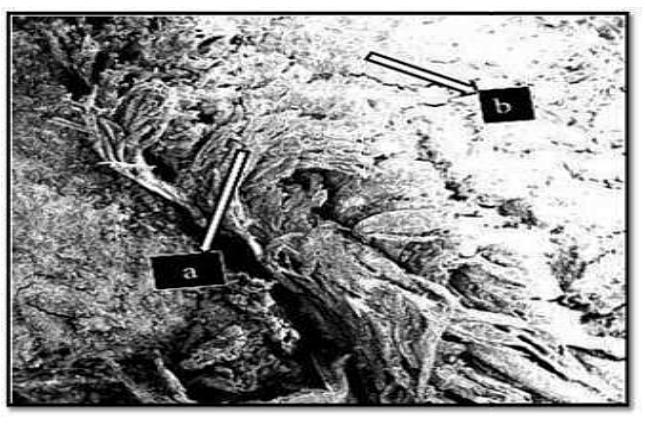

b

Fig. 2. SEM of jute fiber (a) and processed red mud loaded matrix (b). 
Excellent dispersion of red mud-based shielding loaded advanced matrix and good jute fiber-matrix adhesion is observed in the SEM micrograph. Clean and smooth surfaces of pulled out jute fiber can also be seen in the SEM image. Also, the smooth and uniform upper surface is observed in developed biodegradable radiation protection panels.

It is reported in the literature $[20,21]$ that for strong bonding between matrix and jute fibers reinforcement and for better mechanical properties of the developed material, the jute fiber is given proper chemical treatment, especially in alkaline solution, before being used as reinforcement for making composite materials. Here, the red mud-based shielding loaded advanced matrix is in-situ alkaline in nature and consist of varying ceramic shielding phases, strong chemical bonding occurs between lignin present in jute fiber and alkali in advanced matrix as reported in literature and is shown in chemical reaction below:

$$
\text { Lignin }+\mathrm{NaOH}^{-} \rightarrow-\text { lignin }-\mathrm{Na} \text {. }
$$

The chemical reaction involves a breakdown of the network in jute fiber by hydroxide $\left(\mathrm{OH}^{-}\right)$ions and thereby forming a strong interaction in the developed non-toxic, biodegradable radiation shielding panels. Individually the strength of jute fiber will deteriorate, but we obtained the advanced, biodegradable radiation shielding panels with better mechanical strength due to bonding between them.

2.3. X-Ray Attenuation Test of Developed Material in the Form of Panels. The developed biodegradable, non-toxic, jute fiber reinforced, radiation shielding panels were tested for narrow beam X-ray attenuation characteristics by exposing to diagnostic X-ray radiations in the intensity of incident $X$-ray radiations in the range of 40 to $100 \mathrm{kVp}$ for $20 \mathrm{mAs}$ with the X-ray dose used was $5502 \mu \mathrm{Gy}$ without shielding panels. The results obtained were calculated and depicted in Table 2 and Fig. 3.

$\mathrm{T}$ a b 1 e 2

Percentage Attenuation in Developed Material at Different Energies of X-Ray

\begin{tabular}{|c|c|c|c|c|c|}
\hline \hline \multirow{2}{*}{ No. } & \multirow{2}{*}{$\begin{array}{c}\text { Percentage } \\
\text { attenuation }\end{array}$} & \multicolumn{4}{|c|}{ X-ray radiation dose $(\mathrm{kVp})$} \\
\cline { 3 - 6 } & & 40 & 60 & 80 & 100 \\
\hline 1 & $\mathrm{~A}$ & 98 & 90 & 85 & 82 \\
\hline 2 & $\mathrm{~B}$ & 99 & 96 & 90 & 88 \\
\hline
\end{tabular}

In advanced, non-toxic, biodegradable, jute fiber reinforced, X-ray radiation protection panel $\mathrm{A}$, the attenuation percentage was found to be 98 to 82 and in another radiation protection panel B, attenuation percentage was found to be 88 to 99 when 40 to $100 \mathrm{kVp}$ energies of X-ray is applied. It can be easily evaluated from the results that both the types of biodegradable, non-toxic protection panels gives the excellent $\mathrm{X}$-ray radiation protection properties.

Due to the ceramic processing of the red mud with barium sulfate and carbon powder at $1300^{\circ} \mathrm{C}$ various chemical reaction takes place which leads to the formation of varieties of ceramic phases with multi-elemental compositions and multi-layered crystal structures like, silicates of barium, iron, titanium, namely, bafertisite in tailored shielding powder, which has shielding properties. Thus the tailored shielding precursor powder of red mud, which was chemically formulated and mineralogically designed - multi-component - multi-phases was successfully be utilized for making advanced radiation protection panels with jute fiber reinforcement. 


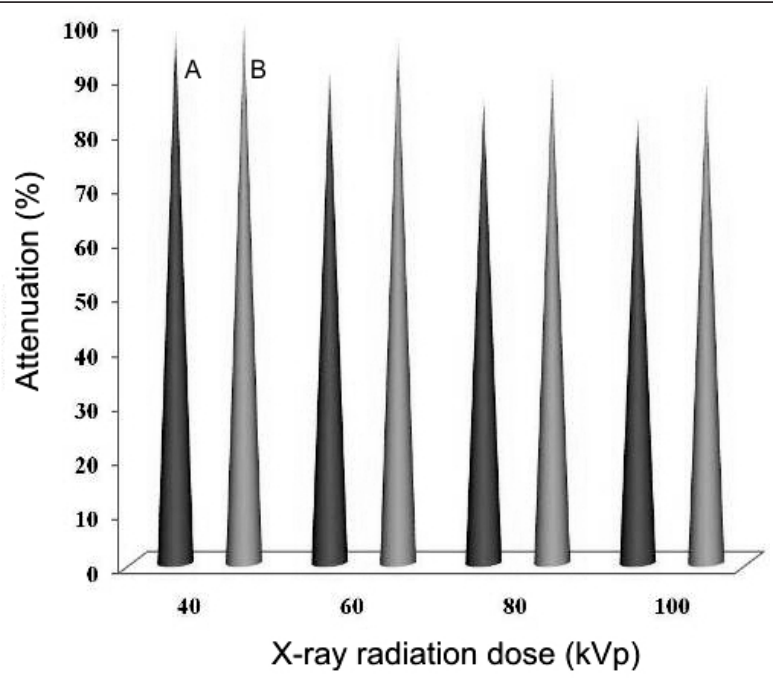

Fig. 3. Attenuation in panels $\mathrm{A}$ and $\mathrm{B}$ at different energies of X-ray.

Thus, the developed advanced, non-toxic, biodegradable, jute fiber reinforced, X-ray radiation protection panels can be used successfully for the construction of X-ray diagnostic $\mathrm{CT}$ scanner rooms to provide adequate shielding against $\mathrm{X}$ photons.

2.4. Mechanical Properties. The developed advanced, non-toxic, biodegradable, jute fiber reinforced, X-ray radiation protection panels with varying jute fiber reinforcement were tested for various mechanical properties as per ASTM.

2.4.1. Flexural Strength. The flexural strength of the biodegradable, non-toxic shielding panels have been calculated. The test results are depicted in Fig. 4, which shows that the flexural strength of jute fiber reinforced shielding panel B is higher than other reinforced shielding panel $\mathrm{A}$. This is due to the fact that the flexural strength depends on the quantity and durability of reinforced jute fiber which has been used for their fabrication. As, the fiber is capable of transferring the greater stress between the loaded shielding matrix and reinforced jute fiber and, thus, results in a better flexural strength of the developed biodegradable, non-toxic shielding panels.

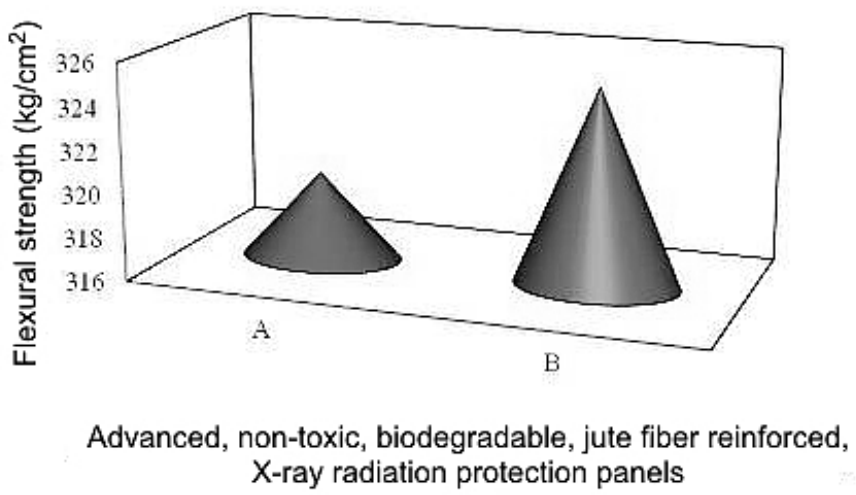

Fig. 4. Flexural strength of developed panels.

2.4.2. Tensile Strength. Figure 5 shows the tensile strength with varying jute content in the sample. The tensile strength is found to increase on increasing the percentage of jute 
content in the developed radiation protection panel. At low fiber content, the composites showed poor tensile strength because of more matrix content and low jute fiber content, which ultimately leads to low load transfer capability.

2.4.3. Impact Strength. The loss of energy during impact is the energy absorbed by the sample. For studying the toughness of the developed biodegradable, non-toxic shielding panels the impact strength was studied and the result is depicted in Fig. 6. We get good test results which may be due to the fact that jute fiber being natural fiber contains an excellent amount of cellulose and lower microfibril angle which results in better work of fracture in impact testing. As the fiber provides strength for the developed shielding panel and the jute fiber percentage in the panel $\mathrm{B}$ is more than $\mathrm{A}$, thus, the non-toxic, radiation, protection panel $\mathrm{B}$ gave better impact strength than the non-toxic, radiation protection panel $\mathrm{A}$.

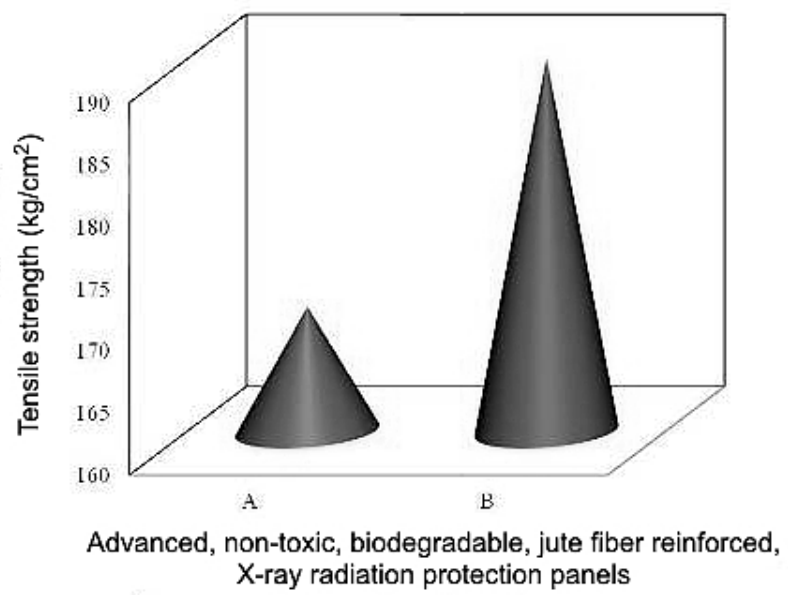

Fig. 5. Tensile strength of developed panels.

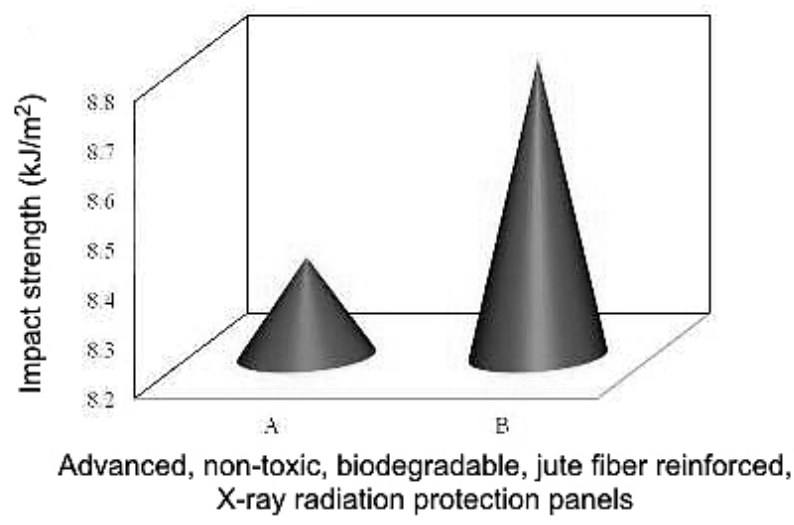

Fig. 6. Impact strength of developed panels.

2.4.5. Water Absorption Test. Water uptake of fractured, advanced, non-toxic, biodegradable, jute fiber reinforced, X-ray radiation protection panels were measured by immersing them in water for about $25 \mathrm{~min}$ at the room temperature of $25^{\circ} \mathrm{C}$. After constant time intervals of five minutes, the samples were taken out of the water, dried and their weight gain was calculated. In samples A and B, water uptake was found to be about 17 to $24 \%$ after initial $5 \mathrm{~min}$, whereas about 34 to $42 \%$ water uptake was found after $25 \mathrm{~min}$. Due 
to the easy penetration of water molecules through the pores of the fractured edge of the sample, the rate of water absorption during initial few minutes is more in comparison to the rest of the time. Water uptake of the panels depends on the water absorption properties of the jute fiber, red mud-based shielding matrix and also on interfacial adhesion. Although the jute fiber is hydrophilic in nature, i.e., having the greater affinity towards water, the red mud-based shielding matrix is hydrophobic in nature, so the developed X-ray radiation protection panels are not so sensitive to water.

Toughening mechanisms increased the properties of developed jute fiber reinforced advanced shielding panels. Further, the jute fibers reinforced protection panels B reported the higher mechanical properties due to the strong jute fibers which also helped in transferring the red mud-based polymeric shielding loaded matrix to share the load, i.e., greater stress-transfer from the matrix to the jute fibers. Also the jute fibers have chemically reacted with alkaline tailored shielding powder having multi-components, e.g., like barium silicate, barium titanate etc. of red mud-based polymeric shielding loaded matrix so as to form a strong bond between them and thereby increasing the mechanical strength to the developed advanced non-toxic radiation shielding panels as reported in literature [22].

Therefore, these observations indicate that the jute fiber woven developed radiation protection panels can be used as potential material to reinforce composites due to their non-toxic good mechanical properties.

The fabrication of newly advanced non-toxic, biodegradable radiation protection panels has been developed successfully by utilizing red mud, an industrial waste. In this novel process ceramic treatment of red mud powder has been developed with barium sulfate and carbon powder as an additive and reducing agent. to obtain black colored tailored radiation shielding precursor powder. The multi-component, multi-elementals multiphase present in red mud tetragonal anatase and rutile - tetragonal, hexagonal cancrinite, cubic hematite and orthorhombic boehmite chemically reacts which results in the formation of alkaline black coloured tailored radiation shielding precursor powder of red mud powder having important shielding phase like bafertisite, barium silicate etc. as confirmed by XRD and SEM analysis [11]. This alkaline tailored powder was then blended with the unsaturated polyester resin having MEKP as catalyst and cobalt octoate as a promoter in it, where simultaneously and synergistically chemical reactions occurs among the various chemical ions present in tailored powder and polymeric matrix to develop a shielding precursor gel as reported in the literature. The shielding gel was then converted into hard solid by the process of chemical cross-linking between different chemical ions, which leads to the formation of tightly bounded three-dimensional structure giving strength to the polymeric block. This designing of molecular moieties leads to explore black color dilatant gel having multifunctional characteristics and was used for developing advanced $\mathrm{X}$-ray protection panels using jute fiber reinforcement by utilizing simple, hand lay-up manual technique.

The developed advanced non-toxic, biodegradable, jute reinforced radiation protection panels can be used as enclosures, partitions or walls as they are easy to handle and can be assembled in X-ray and CT scanner rooms where patients and technician, are easily exposed to X-ray radiation.

Conclusions. Based on the results of the present studies, carried out for the improvement of strength and radiation protection properties of biodegradable jute fiber reinforced material by utilizing red mud-based gel following conclusions can be drawn:

1. The results obtained represent the fundamental starting point for utilization of industrial waste namely, red mud as resource material thereby its ceramic processing leads to tailored shielding precursor powder, which was blended with polyester resin to form thick viscous gel type material used for development of advanced, non-toxic, biodegradable, $\mathrm{X}$-ray radiation protection materials by using jute fiber reinforcement. 
2. The X-ray radiation protection materials were developed in the form of panels by using closed mold fabrication system, with hand layup manual technique with jute fiber reinforcement of different dimensions, i.e., $30 \times 30 \times 0.5 \mathrm{~cm}$ and $30 \times 30 \times 1 \mathrm{~cm}$.

3. The developed $\mathrm{X}$-ray radiation protection materials gave excellent results for the various energies of X-ray photons, i.e., 40, 60, 80, and $100 \mathrm{kVp}$ and, therefore, can be successfully used as radiation protection material.

4. The composition of $\mathrm{B}$ is giving better shielding attenuation results than $\mathrm{B}$ as it is having the higher density.

5. The developed advanced, X-ray radiation protection material also gave excellent results for their mechanical properties as per the standard method of ASTM and found to possess the same strength to the conventional protection material used, as required by the ASTM standards.

6. Although the sample B showed better strength than sample A probably due to the presence of more percentage of jute fiber reinforcement which is responsible for transferring the red mud-based polymeric shielding loaded matrix to share the load, i.e., greater stress-transfer from the matrix to the jute fibers.

7. The scanning electron microphotographs of developed advanced, X-ray radiation protection material were studied to examine and strong interaction between the jute fiber reinforcement and red mud-based alkaline matrix has been observed.

8. Both the developed advanced X-ray radiation protection material in the form of panels showed simultaneously better results for X-ray radiation protection and mechanical properties and thus can be successfully used in X-ray and CT scanner rooms where patients and technician, are exposed to $\mathrm{X}$-ray radiations.

9. The process has successfully utilized and save the cost of chemicals like iron, titanium compounds which are inherently present in red mud otherwise required for making radiation protection materials with the required strength.

Acknowledgments. Special thanks are due to CSIR-HRDG, New Delhi, India for providing financial support to this novel research work. Authors are grateful to Director CSIR-AMPRI Bhopal for providing necessary institutional facilities and encouragement. Mr. Ketan Aptae of Apt Medical Systems Pvt. Ltd., Pune, India for providing X-ray attenuation properties of the developed advanced, non-toxic, biodegradable, jute fiber reinforced, X-ray radiation protection material in the form of panels.

\section{Резюме}

На сьогодні широке застосування отримали композити, армовані натуральними волокнами (екокомпозити). На відміну від склопластиків, вони схильні до біодеградації і нешкідливі для навколишнього середовища, мають низьку вартість і щільність, не виділяють шкідливих речовин при горінні і розщеплюються мікроорганізмами. Запропоновано нову технологію виробництва з червонозему здатного до біодеградації джутоволоконного матеріалу з високими міцнісними та радіаційно-захисними властивостями. Оцінено проникність його рентгенівськими променями, статичну міцність при розриві і згині, а також ударну міцність. Проведено мікроструктурні дослідження. Отримані результати підтверджують перспективність запропонованої технології виробництва 3 цього матеріалу захисних панелей для рентгенівських кабінетів та іншого обладнання радіаційного захисту.

1. Y. I. Akkurt, H. Akyildirim, B. Mavi, et al., "Photon attenuation coefficients of concrete includes barite at the different rate," Ann. Nucl. Energy, 37, No. 7, 910-914 (2010). 
2. J. P. McCaffrey, H. Shen, B. Dowton, and E. Mainegra-Hing, "Radiation attenuation by lead and nonlead materials used in radiation shielding garments," Med. Phys., 34, No. 2, 530-537 (2007).

3. G. Bogoeva-Gaceva, M. Avella, M. Malinconico, et al., "Natural fiber eco-composites," Polym. Composite., 28, No. 1, 98-107 (2007).

4. H. L. Bos, K. Molenveld, W. Teunissen, et al., "the Compressive behaviour of unidirectional flax fiber reinforced composites," J. Mater. Sci., 39, No. 6, 2159-2168 (2004).

5. S. Misra, M. Misra, S. S. Tripathy, et al., "The influence of chemical surface modification on the performance of sisal-polyester biocomposites," Polym. Composite., 23, No. 2, 164-170 (2002).

6. A. K. Mohanty, L. T. Drzal, and M. Misra, "Engineered natural fiber reinforced composites: influence of surface modifications and novel powder impregnation processing," J. Adhes. Sci. Technol., 16, No. 8, 999-1025 (2002).

7. http://www.compositesworld.com/news/cwweekly/2006/marchnews.

8. G. I. Williams and R. P Wool, "Composites from natural fibers and soy oil resins," Appl. Compos. Mater., 7, Nos. 5-6, 421-432 (2000).

9. R. S. Thakur and S. N. Das, Red Mud: Analysis and Utilization, PID and Wiley Eastern Ltd., New Delhi, India (1994).

10. R. U. Ayres, H. John, and A. Bjorn, "Utilization of the wastes in the new millennium," MRSI Bull., 7, 477-480 (2010).

11. S. Verma, S. S. Amritphale, and S. Das, "Development of advanced, X-ray radiation shielding panels by utilizing red mud-based polymeric organo-shielding gel-type material," Waste Biomass Valori., 8, No. 6, 2165-2175 (2017).

12. A. Akinci, H. Akbulut, and F. Yilmaz, "The effect of the red mud on polymer crystallization and the interaction between the polymer-filler," Polym.-Plast. Technol., 46, No. 1, 31-36 (2007).

13. A. Bindal, S. Singh, N. K. Batra, and R. Khanna, "Development of glass/jute fibers reinforced polyester composite," Indian J. Mater. Sci., 2013, Article ID 675264 (2013), DOI: 10.1155/2013/675264.

14. J. P. Davim, P. Reis, and C. C. Antonio, "Experimental study of drilling glass fiber reinforced plastics (GFRP) manufactured by hand lay-up," Compos. Sci. Technol., 64, No. 2, 289-297 (2004).

15. G. H. Jeffery, J. Bassett, J. Mendham, and R. C. Denney, Vogel's Textbook of Quantitative Chemical Analysis, 5th edn, John Wiley \& Sons Inc., New York (1989).

16. ASTM D790-17. Standard Test Methods for Flexural Properties of Unreinforced and Reinforced Plastics and Electrical Insulating Materials, ASTM International, West Conshohocken, PA (2017).

17. ASTM D638-14. Standard Test Method for Tensile Properties of Plastics, ASTM International, West Conshohocken, PA (2014).

18. ASTM D256-10. Standard Test Methods for Determining the Izod Pendulum Impact Resistance of Plastics, ASTM International, West Conshohocken, PA (2010).

19. B. Bose, Effect of Water Absorption on the Mechanical Properties of Jute Fiber Reinforced Polymer Composites, BSc Thesis, Bangladesh University of Engineering \& Technology (BUET), Dhaka, Bangladesh (2005). 
20. M. Rokbi, H. Osmani, A. Imad, and N. Benseddiq, "Effect of chemical treatment on flexure properties of natural fiber-reinforced polyester composite," Procedia Engineer., 10, 2092-2097 (2011).

21. E. F. Rodrigues, T. F. Maia, and D. R. Mulinari, "Tensile strength of polyester resin reinforced sugarcane bagasse fibers modified by etherification," Procedia Engineer., 10, 2348-2352 (2011).

22. M. J. Bagnell and W. R. Ivy, Radiation Shielding Structures, US Patent No. 4514640. Valid since April 30, 1985.

Received 21. 03. 2017 